\title{
ARTHROSCOPIC SUBACROMIAL DECOMPRESSION FOR CHRONIC IMPINGEMENT
}

\author{
TWO- TO FIVE-YEAR RESULTS
}

HARVARD ELLMAN, STEPHEN P. KAY

From UCLA Center for the Health Sciences, Los Angeles

\begin{abstract}
Subacromial decompression was performed arthroscopically on 65 patients who were evaluated two to five years after the procedure. None had full thickness rotator cuff tears. Patients with partial thickness cuff tears were included in this study in order to allow comparison of arthroscopic acromioplasty with open acromioplasty for stage II impingement.

On the UCLA shoulder rating scale, $89 \%$ of the cases in this study achieved a satisfactory result. These results compare favourably with those reported following open acromioplasty. The arthroscopic procedure is technically demanding. When properly performed in patients with appropriate indications, hospitalisation is brief, return to activities is rapid, there is little risk of deltoid muscle complications, and the results are lasting.
\end{abstract}

Anterior acromioplasty for the treatment of chronic impingement syndrome in the shoulder has been well documented (Pujadas 1970; Neer 1972, 1983; Hawkins and Kennedy 1980; Post and Cohen 1985; Raggio, Warren and Sculco 1985). The arthroscopic technique was first performed by the senior author in 1983. A preliminary report (Ellman 1985), and a short-term follow-up study of 50 cases (Ellman 1987) suggested that the technique of arthroscopic subacromial decompression (ASD) is an effective alternative to the open operation.

The purpose of this prospective study is to evaluate the longer term results of ASD in a group of 65 cases who were without evidence of full thickness rotator cuff tears. Partial thickness tears (not usually discernible without arthroscopy) were included in this series in order to allow comparison of arthroscopic acromioplasty with the open technique.

H. Ellman, MD, Associate Clinical Professor

S. P. Kay, MD, Clinical Instructor

Division of Orthopaedic Surgery, UCLA Center for the Health Sciences, Los Angeles, California, USA.

Correspondence should be sent to Dr H. Ellman at 2080 Century Park East, Suite 1500, Los Angeles, California 90067, USA

(C) 1991 British Editorial Society of Bone and Joint Surgery 0301-620X/91/3137\$2.00

J Bone Joint Surg [Br] 1991 ; 73-B:395-8.

\section{PATIENTS AND METHODS}

Between November 1983 and November 1986, the senior author performed 90 arthroscopic subacromial decompressions (ASDs). Eighty-two of these patients were available for a minimum follow-up of two years. The longest follow-up was five years. Seventeen of these 82 patients had stage III impingement (full thickness rotator cuff tears) and were excluded; the remaining 65 patients had stage II impingement, without full thickness tears, and are the subject of this study.

Thirty-one were male, 34 were female and the dominant shoulder was involved in 39 . The average age was 45 years at the time of surgery. Night pain was a significant complaint in 59 of the patients. The mean duration of symptoms prior to surgery was just over two years; no patient had suffered pain for less than six months. Two-thirds of these patients had crepitus about the shoulder during passive movements.

The impingement sign, as described by Neer (1983), was present in every patient, and was a necessary physical finding for establishing the diagnosis. An impingement test was performed on all patients using approximately 10 cc of $1 \%$ lignocaine (lidocaine USAN) injected directly into the subacromial space. Prompt and profound diminution of symptoms from the injection was also a prerequisite for establishing the diagnosis, which was then confirmed arthroscopically prior to decompression. 
Pre-operative radiographs included a $30^{\circ}$ caudal tilt view or a supraspinatus outlet view. A spur was seen on the undersurface of the anterior aspect of the acromion in most patients. Calcific deposits were seen in the rotator cuffs of 14 patients.

Pain was the chief complaint of every patient in this study. Impairment of function and stiffness were less frequent complaints. All three parameters were quantified using the modified UCLA shoulder rating scale (Table I). In this system, pain and function are each rated, independently, on a scale of 1 to 10 , with 1 being the worst possible score, and 10 being awarded to a symptom-free shoulder. Range of motion, muscle strength, and patient satisfaction are also included, giving a maximum value of 5 points each. The maximum score on the UCLA scale would therefore be $10+10+$ $5+5+5$, (35 points). Results were divided into excellent ( 34 to 35 points), good ( 28 to 33 ), fair (21 to 27 ), and poor (20 or less points). Good or excellent scores ( $>28$ ) were considered 'satisfactory', while fair or poor scores were 'unsatisfactory'.

Pre-operatively, the mean pain rating for the 65 shoulders in this study was 2.8 , indicating 'pain, continuous but bearable all of the time, requiring strong medication occasionally'.

Function was less severely affected. The average 'function' score on the UCLA scale pre-operatively was 5.1 , indicating that the patient was 'restricted to light work, but capable of performing most activities of daily living'. Pre-operative active shoulder flexion was about $150^{\circ}$ (range $90^{\circ}$ to $175^{\circ}$ ).

Conservative treatment was carried out in all patients for a minimum of six months (average just over two years) prior to surgery. This consisted of oral nonsteroidal anti-inflammatory drugs in every patient who could tolerate them, local steroid injections in most (average 4.2 injections, range 0 to 30 ), and physical therapy. Many of the patients in this study had undergone prolonged treatment prior to their referral to the author, so no standard regime of conservative treatment had been employed.

\section{SURGICAL TECHNIQUE}

The detailed technique of ASD has been previously described by the senior author (Ellman 1988, 1989). The patient is positioned in the lateral decubitus position, and, using a counter-traction weight of 10 to $15 \mathrm{lb}$ (4.5 to $7 \mathrm{~kg}$ ), the arm is abducted $15^{\circ}$. The coracoid process, distal clavicle, acromioclavicular joint and acromion are palpated and outlined with a marking pen. Anterolateral, posterolateral, and posterior portals are placed, with orientation pins to indicate the attachment of the coracoacromial ligament to the acromion. A synovial shaver is introduced through the anterolateral portal and debridement of inflamed bursal tissue is performed. An electrosurgical knife is used to cut the coracoacromial
Table I. UCLA shoulder rating scale (modified)

\begin{tabular}{|c|c|c|c|}
\hline & Score & & Score \\
\hline \multicolumn{4}{|c|}{ Active forward flexion } \\
\hline $\begin{array}{l}\text { Present always and } \\
\text { unbearable; strong }\end{array}$ & 1 & Greater than $150^{\circ}$ & $\begin{array}{l}5 \\
4\end{array}$ \\
\hline $\begin{array}{l}\text { medication frequently } \\
\text { Present always but bearable; }\end{array}$ & 2 & $\begin{array}{l}90^{\circ} \text { to } 120^{\circ} \\
45^{\circ} \text { to } 90^{\circ}\end{array}$ & $\begin{array}{l}3 \\
2\end{array}$ \\
\hline $\begin{array}{l}\text { strong medication } \\
\text { occasionally }\end{array}$ & & $\begin{array}{l}30^{\circ} \text { to } 45^{\circ} \\
\text { Less than } 30^{\circ}\end{array}$ & $\begin{array}{l}1 \\
0\end{array}$ \\
\hline None or little at rest, present & 4 & & \\
\hline $\begin{array}{l}\text { during light activities; } \\
\text { salicylates frequently }\end{array}$ & & \multicolumn{2}{|l|}{$\begin{array}{l}\text { Strength of forward flexion } \\
\text { (manual muscle-testing) }\end{array}$} \\
\hline Present during heavy or & 6 & Grade 5 (normal) & 5 \\
\hline $\begin{array}{l}\text { particular activities only; } \\
\text { salicylates occasionally }\end{array}$ & & & $\begin{array}{l}4 \\
3\end{array}$ \\
\hline $\begin{array}{l}\text { salicylat } \\
\text { Occasio }\end{array}$ & 8 & $\begin{array}{l}\text { Grade } 3 \text { (fair) } \\
\text { Grade } 2 \text { (poor) }\end{array}$ & $\begin{array}{l}3 \\
2\end{array}$ \\
\hline $\begin{array}{l}\text { None } \\
\text { Nonio }\end{array}$ & 10 & Grade 1 (muscle & 1 \\
\hline \multicolumn{2}{|l|}{ Function } & Grade 0 (nothing) & 0 \\
\hline Unable to use limb & 1 & & \\
\hline Only light activities possible & 2 & \multirow{5}{*}{$\begin{array}{l}\text { Satisfaction of the patient } \\
\text { Satisfied and better } \\
\text { Dissatisfied and worse }\end{array}$} & \\
\hline $\begin{array}{l}\text { Able to do light housework or } \\
\text { most activities of daily living }\end{array}$ & 4 & & $\begin{array}{l}5 \\
0\end{array}$ \\
\hline $\begin{array}{l}\text { Most housework, shopping, } \\
\text { and driving possible; able to } \\
\text { do hair and to dress and } \\
\text { undress, including fastening } \\
\text { brassière }\end{array}$ & 6 & & \\
\hline \multirow{2}{*}{$\begin{array}{l}\text { Slight restriction only; able } \\
\text { to work above shoulder level } \\
\text { Normal activities }\end{array}$} & 8 & & \\
\hline & 10 & & \\
\hline \multicolumn{4}{|c|}{ Maximum score 35 points: } \\
\hline \multicolumn{2}{|c|}{$\left.\begin{array}{l}\text { Excellent }=34 \text { to } 35 \\
\text { Good }=28 \text { to } 33\end{array}\right\}$ Satisfactory } & \multicolumn{2}{|l|}{$\begin{array}{l}\text { Fair }=21 \text { to } 27 \\
\text { Poor }=20 \text { or less }\end{array}$} \\
\hline
\end{tabular}

ligament, to morcellate the bursal tissue on the undersurface of the acromion, and to maintain haemostasis throughout the procedure. A high volume and rapid rate of irrigation is maintained throughout the procedure.

One major difference between our current technique and that originally described is the use of the rightangled, plastic coated meniscal electrode. This instrument is capable of cutting in normal saline, thereby obviating the need for constant switching to distilled water from saline and back again. On occasion, we have also used a fluid irrigation pump, which helps to obtain

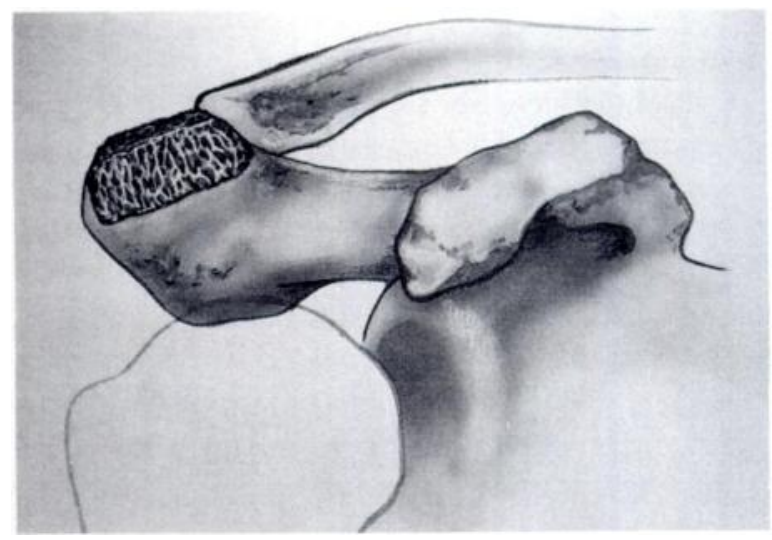

Fig. 1

The completed acromioplasty extends across the full width of the acromion and removes the hook-like projection from the anterior undersurface. 
haemostasis, but which must be used with caution lest over-distention should produce extravasation.

Once the soft tissue is removed from the undersurface of the acromion, an acromioplasty is performed using a powered burr removing the hook-like projection of a type 3 acromion as well as any spurs. The completed procedure must meet all the criteria established for an open acromioplasty (Fig. 1). Any calcific deposits are needled under arthroscopic vision.

\section{RESULTS}

Satisfactory results were achieved in 58 of the 65 patients $(89 \%)$ and 32 of them were classed excellent. Four patients had fair results and three poor. Pain relief was the most dramatic benefit but function also improved. The mean pain rating of 2.8 improved to 8.2 (slight discomfort and occasional pain). Thirty-six of the 65 shoulders became completely pain free $(55 \%)$.

Postoperative function averaged 8.8 on the UCLA scale (compared with 5.1 before operation). This implies the ability to perform activities of daily living (including driving, shopping and dressing), and to work above shoulder level with only, on occasion, slight restrictions. Thirty-nine patients reported no functional restrictions at all $(60 \%)$.

Pre-operative forward flexion (average $150^{\circ}$ ) improved to $158^{\circ}$ postoperatively (range $125^{\circ}$ to $180^{\circ}$ ). This change was not statistically significant. There was no indicative change in shoulder strength.

All patients in this series returned to activities of daily living within a few days of their operation. Postoperatively, the patients were not given a sling, and they were encouraged to use the arm. Most patients who had desk jobs returned to the office within two or three days; those whose jobs required repetitive overhead activities, especially strenuous lifting, usually took six weeks or longer.

In this study there were 17 worker's compensation patients of whom 14 achieved a satisfactory result. Two of these patients are still disabled, two have reached retirement age and are no longer working, two are employed at a less strenuous occupation, and 11 have returned to their regular job.

Thirty-two patients in this series had been active in recreational sports and 29 returned to a level of participation with which they were satisfied. There were, however, no collegiate or professional athletes in this series.

No attempt was made to correlate the extent of surgical pathology with the postoperative result, but impingement was verified in each patient prior to ASD. Unlike the pristine subacromial space seen in patients whose shoulders have been arthroscoped for other pathology, the subacromial space of these patients was filled with hypertrophic fibrous bands of bursal stroma, often hung with clumps of fibro-fatty tissue. Hyperaemia was often observed. Surface ulcerations were identified on the rotator cuff in a number of cases.

Complications. There have been very few complications associated with this procedure. Early in the series, three patients complained of transient dysaesthesia in the distribution of the superficial branch of the radial nerve on the dorsum of the thumb. This probably resulted from inadequate padding of the traction device at the wrist; there has been no case of traction neuropathy involving the brachial plexus. One patient experienced leaking from both the anterolateral and posterior portals but this ceased in one week with local wound care and antibiotic ointment. Another patient developed a local haematoma at the site of the anterior portal which resolved spontaneously. No ectopic bone formation has been seen in association with the bone fragments produced by mechanical burring. There has been no cases of deep infection.

A few intra-operative problems related to instrument failure have occurred and were dealt with arthroscopically. Extravasation of fluids during arthroscopy will generally produce a sizeable regional swelling. No compartment syndromes have developed, and distension has not involved the axillary area.

\section{DISCUSSION}

Although the relative contributions of hypovascularity in the critical zone and mechanical factors have yet to be fully elucidated, most shoulder surgeons believe that mechanical impingement plays a significant role in rotator cuff lesions. Numerous studies have already demonstrated the efficacy of decompression operations performed through a standard, open approach (Neer 1972; Ha'eri and Wiley 1982; Post and Cohen 1985; Thorling et al 1985; McShane, Leinberry and Fenlin 1987), but there have been few long-term studies of decompression performed through the arthroscope. We have demonstrated an $89 \%$ success rate for ASD even up to five years. Our short-term results (Ellman 1987) have not deteriorated with time.

Numerous authors have stressed the importance of postoperative therapy in obtaining a good result (Ha'eri and Wiley 1982; Neviaser et al 1982; Post and Cohen 1986). They stress the importance of sparing the origin of the deltoid, so that rehabilitation can be started early. McShane et al (1987) reported significantly better results by modifying his procedure to a deltoid-splitting approach. One can think of ASD as the ultimate in deltoidsparing. The patients were operated as out-patients and were sent home with no sling. They were encouraged to begin using their arm immediately for all activities of daily living.

Impingement symptoms were associated with calcific deposits in 14 cases in this series. Most responded to injection or other conservative management and resorption eventually occurs (DePalma and Kruper 1961; 
Uhthoff, Sarkar and Maynard 1976). The arthroscopic procedure was reserved for those patients who had remained symptomatic for more than two years. ASD and concomitant needling and curettage of the calcific deposit produced a satisfactory outcome in each case.

In theory, the timely decompression of a partial thickness rotator cuff tear should retard deterioration to a full thickness tear. The undersurface of the rotator cuff was not routinely examined for partial thickness tears in the early cases of this series and so a statistical comparison between patients with no tear and those with partial thickness tears cannot be made. However, results in patients with known partial thickness tears were mainly good to excellent. It is our current protocol to debride and decompress grade 1 and grade 2 (Ellman 1990) partial thickness tears involving less than one-half the thickness of the cuff, except in cases involving the dominant arm of an individual involved in strenuous overhead activities. In these individuals, a traditional cuff repair is preferred. The result of this method of treatment is being investigated prospectively.

For patients with primary impingement, calcific tendinitis, or partial thickness rotator cuff tears who have failed conservative management, ASD is our procedure of choice. It is contra-indicated in patients with impingement secondary to shoulder instability. With the right indications and in skilled hands, the results of ASD are equal to or better than the results of open acromioplasty. Patients recover faster and have less risk of deltoid muscle complications. The results are now seen to stand the test of time.

The authors acknowledge the contribution of Earl Gomberg in maintaining the computerised statistics for this study, and express their appreciation to Phyllis Cobb and Maureen McAdam for their assistance in preparing this manuscript.

No benefits in any form have been received or will be received from a commercial party related directly or indirectly to the subject of this article.

\section{REFERENCES}

DePalma AF, Kruper JS. Long-term study of shoulder joints afflicted with and treated for calcific tendinitis. Clin Orthop 1961; 20:61-72.

Ellman H. Arthroscopic subacromial decompression: a preliminary report. Orthop Trans 1985; 9:49.

Ellman H. Arthroscopic subacromial decompression: analysis of 1-3 year results. Arthroscopy 1987; 3:173-81.

Ellman H. Arthroscopic subacromial decompression. In : Parisien JS, ed. Arthroscopic surgery. New York: McGraw-Hill, 1988; 243-8.

Ellman H. Arthroscopic treatment of impingement of the shoulder. In AAOS Instructional Course Lectures. 1989; 38:177-85.

Ellman H. Diagnosis and treatment of incomplete rotator cuff tears. Clin Orthop 1990; $254: 64-74$.

Ha'eri GB, Wiley AM. Shoulder impingement syndrome - results of operative release. Clin Orthop 1982; 168:128-32.

Hawkins RJ, Kennedy JC. Impingement syndrome in athletes. Am J Sports Med 1980; 8:151-8.

MaShane RB, Leinberry CF, Fenlin JM. Conservative open anterior acromioplasty. Clin Orthop 1987; 223:137-44.
Neer CS II. Anterior acromioplasty for the chronic impingement syndrome in the shoulder: a preliminary report. J Bone Joint Surg [Am] 1972; 54-A :41-50.

Neer CS II. Impingement lesions. Clin Orthop 1983; $173: 70-7$.

Neviaser TJ, Neviaser RJ, Neviaser JS, Neviaser JS. The four-in-one arthroplasty for the painful arc syndrome. Clin Orthop 1982;163; $107-12$.

Post M, Cohen J. Impingement syndrome: a review of late stage II and early stage III lesions. Orthop Trans 1985; 9:48.

Post M, Cohen J. Impingement syndrome : a review of late stage II and early stage III lesions. Clin Orthop 1986; $207: 126-32$.

Pujadas GM. Coracoacromial ligament syndrome. J Bone Joint Surg [Am] 1970; 52-A :1261.

Raggio CL, Warren RF, Sculco T. Surgical treatment of impingement syndrome: 4 year follow-up. Orthop Trans 1985; 9:48-9.

Thorling J, Bjemeld H, Hallin G, Hovelius L, Hägg O. Acromioplasty for impingement syndrome. Acta Orthop Scand 1985; 56:147-8.

Uhthoff HK, Sarkar K, Maynard JA. Calcifying tendinitis: a new concept of its pathogenesis. Clin Orthop 1976; 118:164-8. 